\title{
Comensalidade e refeição na cultura popular do Cristianismo Primitivo
}

\author{
Commensality and meal in the popular culture \\ of Early Christianity
}

\section{Commensalidad y comida en la cultura popular del cristianismo primitivo}

\author{
Danielle Lucy Bósio Frederico*
}

\begin{abstract}
RESUMO
O presente artigo tem como objetivo apresentar a comida como elemento estruturante de uma sociedade e como chave hermenêutica para a pesquisa de textos que compõem a história do cristianismo primitivo. Para tanto nos valemos da Antropologia da Comida, um ramo de estudo da Antropologia Cultural para nos auxiliar na busca de novas respostas e percepções desses textos. Ao utilizarmos tal ferramenta percebemos o entorno do texto, os grupos presentes, a dinâmica social e suas pretensas intenções pois reconhecemos a presença de códigos à mesa que precisam ser decifrados. $\mathrm{O}$ que se come, onde e com quem se come tornam-se dados relevantes para um melhor entendimento do contexto e consequentemente do texto. Palavras-chave: Refeição; comensalidade; estratos sociais.
\end{abstract}

\begin{abstract}
This article aims to present food as a structuring element of a society and as a hermeneutic key for the research of texts that make up the history of primitive Christianity. For that, we use Food Anthropology, a branch of Cultural Anthropology study to help us in the search for new answers and perceptions of these texts. When using this tool, we perceive the surrounding of the text, the groups present, the social dynamics and their alleged intentions because we recognize the presence of codes at the table that need to be deciphered. What one eats, where and with whom one eats becomes relevant data for a better understanding of the context and consequently of the text.
\end{abstract}

Keywords: Meal; commensality; social strata.

\section{RESUMEN}

Este artículo tiene como objetivo presentar la comida como un elemento estructurante de una sociedad y como una clave hermenéutica para la investigación de textos que componen la historia del cristianismo primitivo. Para hacerlo, utilizamos Food Anthropology, una rama de estudio en Antropología Cultural para ayudarnos en la búsqueda de nuevas respuestas y percepciones de estos textos. Al usar esta herramienta, percibimos el entorno del texto, los grupos presentes, la dinámica social y sus supuestas intenciones porque reconocemos la presencia de códigos en la mesa que deben ser descifrados. Lo que se come, dónde y con quién se convierte en datos relevantes para una mejor comprensión del contexto y, en consecuencia, del texto.

Palabras clave: Comida; comensalidad; estratos sociales.

* Docente da Faculdade de Teologia da Universidade Metodista de São Paulo (Fateo/Umesp) e doutora em Ciências da Religião (Umesp), com pesquisas sobre o Cristianismo Primitivo. 


\section{As práticas alimentares: presença, códigos e interdisciplinaridade}

A refeição é um tema recorrente na literatura bíblica, desde o mito da criação em Gênesis até o Apocalipse de João. Do fruto proibido comido pelo casal primordial até o banquete messiânico prometido aos fiéis, que também terão acesso à árvore que produz frutos que curam todas as doenças. Em várias narrativas, vemos a comida como sinal de aliança, hospitalidade, cura, purificação e também como marca identitária, quando há refeições ou alimentos específicos que sinalizam a pertença a um determinado grupo. Há refeições que podem indicar contaminação, quando regras pré-estabelecidas são quebradas ou ignoradas ao se comer algo que não se deveria; apesar de não ser possível sabermos, realmente, o que um grupo e/ou uma comunidade comia.

A distinção entre grupos pode ser realizada através daquilo que se come ou não se come. A abstinência ou o jejum também se apresentam como mensagens e interditos utilizados na classificação de pessoas ou grupos, podendo ser utilizados na classificação, separação ou indicação de níveis de santidade ou pureza. Uma seleção de alimentos e de bebidas pode estabelecer desde pertença, poder, exclusão, pobreza, até mesmo eternidade, dependendo do período, do contexto e do objetivo estabelecido por um grupo ou por um povo imerso em teologias próprias de seu tempo e/ou aquelas advindas de interações culturais.

A refeição se constitui em um tema de todas as épocas pois, ao observarmos as sociedades ao longo dos tempos, veremos que a alimentação é uma característica peculiar de um povo e faz parte de sua identidade. Exemplos como o de Perséfone, que, na mitologia grega, ao comer o grão de romã ficou presa a dois mundos; dos deuses do Olimpo, que se alimentavam de mel e ambrosia - alimentos específicos dos deuses. Quando observamos no mundo siro-palestinense o uso frequente do trigo, da cevada, do azeite e do vinho; ou quando entramos no campo das oferendas aos deuses, nos deparamos com o sangue, a carne, o trigo dentre outros cereais. Podemos observar ao mesmo tempo a universalidade do tema e a peculiaridade de cada cultura.

O ser humano escolhe a sua alimentação não somente pelo valor nutricional, mas pelo que ela pode significar em termos culturais e sociais. Fazer uma refeição não era um ato solitário e sem significado na Antiguidade. Na Antiga Mesopotâmia, por exemplo, a base alimentar era o pão e a cerveja, e a participação em uma refeição, além de estabelecer e fortalecer vínculos sociais, poderia selar contratos entre as partes presentes à mesa; estabelecer uma celebração de casamento; e ainda comemorar ou relembrar os mortos. Outro exemplo pode ser observado na Assíria do fim do terceiro milênio, em 
que o fato de untar a cabeça de uma moça livre ou organizar um banquete de núpcias bastava para legitimar um casamento. Um documento de contabilidade Babilônico, do princípio do segundo milênio, mostra que, durante um casamento, o pai da noiva encarregava-se de distrair seus convidados e os convidados do noivo, até que este partisse com sua mulher, depois de terem recebido os presentes, dentre os quais produtos alimentares consumidos durante a festa. A cerimônia em si comportava, dentre outras coisas, uma troca simbólica de iguarias dispostas em uma mesa-bandeja, que eram consumidas, uma após a outra, pelas famílias da noiva e do noivo, criando assim um laço suplementar entre eles (FLANDRIN; MONTANARI, 1998).

Fustel de Coulanges, em seu livro Cidade Antiga, ao situar sua pesquisa na Grécia e na Itália no período da Antiguidade clássica, nos informa que a principal cerimônia no culto doméstico ${ }^{1}$ era um banquete chamado sacrifício e que, nessa cerimônia, a necessidade de se comunicar com a divindade era preenchida. O autor afirma, também, que na adoração ao fogo sagrado, o banquete era considerado o ato religioso por excelência, sendo presidido pelo próprio deus. Era ele quem tinha cozido o pão e preparado os alimentos, por isso era-lhe devida uma oração no começo e outra no fim da refeição. Antes de comer, depositavam sobre o altar primícias do alimento; antes de beber, espalhavam a libação de vinho - parte da divindade cultuada. Ninguém duvidava de que sua presença na cerimônia era real e nem que estivesse ali para comer e beber. Quando a chama se elevava, era a afirmação da presença desse deus. Assim, dividia-se a refeição entre o homem e a divindade; cerimônia sagrada, sem dúvida, pela qual humano e divino entravam em comunhão.

Outro tipo de refeição eram os banquetes anuais nas sepulturas dos antepassados, em que as famílias partilhavam uma refeição regada a vinho junto ao túmulo do morto. Christine M. Tomas nos diz que esse banquete, geralmente, acontecia no dia do aniversário do morto e que, além da refei-

\footnotetext{
Para essa religião doméstica, não existiam regras uniformes, nem um ritual comum. Cada família gozava, a esse respeito, da mais completa independência. Nenhum poder estranho tinha o direito de estabelecer regras para o seu culto ou de firmar normas para a sua crença. Não existia outro sacerdote além do pai, e este, como sacerdote, não conhecia superior hierárquico. O pontífice de Roma ou o arconte de Atenas podiam certificar-se se o pai de família cumpria com todos os seus ritos religiosos, mas não tinham o direito de lhe ordenar nem a mais ligeira alteração em suas leis domésticas de religião. A sua regra era absoluta. Cada família tinha as suas cerimônias, que lhe eram próprias e, do mesmo modo, as suas festas particulares, as suas fórmulas de oração e os seus hinos. Só o pai, único intérprete e único pontífice da sua religião, é que tinha o poder de ensiná-la, e somente a seu filho, sendo que ninguém mais podia ser instruído nas regras da sua religião caseira. Os ritos, as palavras próprias da oração, os cantos, tudo isso preenchendo a parte essencial dessa religião doméstica, era patrimônio, propriedade sagrada que a família com ninguém partilhava, sendo até mesmo proibido revelá-los a estranhos (COULANGES, 2007, p. 41).
} 
ção, eram levadas violetas e rosas. Em Corinto, essa refeição também podia acontecer no primeiro dia de todos os meses (calendas). Nesses locais, havia um espaço específico para se deixar comida e bebida para o falecido, a fim de que seu espírito não viesse a desfalecer (COULANGES, 2007, p. 15). O alimento e a bebida também eram levados, em outros momentos, até a sepultura e introduzidos por um buraco nas sepulturas planas diretamente até o corpo. Muitos vestígios desses banquetes foram encontrados em cemitérios da cidade de Corinto. Há informação ainda de que a fim de que o Banquete fosse realizado mesmo após a morte, o falecido deixava em seu testamento o valor necessário para que este fosse realizado por seus familiares (COULANGES, 2007).

Em todas as refeições havia alimentos típicos de cada região. Quando no Mediterrâneo, temos a chamada "tríade mediterrânea", base de toda a cultura alimentar desta localidade, formada por azeite, farinha e vinho.

Foi esta tríade, já consolidada, existindo possivelmente já antes dos Gregos, que os homens, poéticos e agradecidos, elevaram a nível de divindade, ou para o dizer de um modo mais fácil, outorgaram-lhe divindades protetoras que desempenhavam um papel de intermediárias. Deméter foi a deusa dos trigos e dos seus derivados, das oitenta classes de pão, da pizza e de todo o tipo de pastéis, papas, crepes, etc. Benévola e amiga de dar, concede um dos três máximos bens da subsistência. A segunda é uma divindade sábia, de certo modo hierática, e de qualquer modo perfeita: Atena (AGUILERA, 2001, p. 25).

Como terceira divindade, temos Dioniso, protetor da videira e do vinho, também associado a Deméter, pois, molhar o pão em vinho puro poderia indicar tanto uma maneira de iniciar o dia quanto o valor de uma oração.

Assim, como nos sinaliza Maria Regina Cândido (2012, p. 164):

[...] Arquéstrato (poeta siciliano) como grego tinha a noção que sociedade grega definia o mundo da civilidade grega como parte dos homens comedores de pão, os sitophagos, conceito definido por Homero na Odisseia de Ulisses e reforçado por Hesíodo nos Trabalhos e os Dias. A sociedade dos helenos vivia do cultivo de grãos e de cuidados com o gado nas pastagens. Ambos resultam em produtos considerados dádivas dos deuses, que permitia aos gregos se alimentarem de pão produzido a partir dos cereais de Demeter e Perséfone. A carne seria proveniente de animais domésticos em sacrifícios aos deuses, bebem do vinho fornecido por Dionísio e usam do cultivo do azeite cuja techné foi ensinada por Atena.

Tanto humanos quanto deuses possuem suas predileções com respeito aos itens alimentares, os quais possuem significados específicos, sendo categorizados como especiais, mágicos, sagrados, nobres ou populares. Assim, o que se encontra no prato e aquilo que ingerimos, constitui-se em uma rede 
de significados construídos ao longo de períodos e pode auxiliar no entendimento de uma sociedade, de um grupo ou mesmo de indivíduos, que se norteiam a partir de pressupostos estabelecidos na sociedade em que vivem ou em grupos dos quais fazem parte. Essa socialização, base da estruturação da vida em sociedade, precisa ser entendida como:

[...] sendo o processo de integração de um indivíduo a uma dada sociedade ou a um grupo particular pela interiorização dos modos de pensar, de sentir e agir, ou seja, dos modelos culturais próprios a esta sociedade ou a este grupo (CUCHE, 2002, p. 102).

Tais comportamentos auxiliam na identificação de variados grupos que, quando observados no todo social, se encontram divididos em dois polos desiguais e interdependentes: elite e população. Dois polos que podem ser caraterizados pelas peculiaridades no ato de comer ou na gastronomia escolhida, no espaço e na companhia em que esse ato se desenvolve. Dennis Smith falando sobre a ideologia do banquete, cita Mary Douglas dizendo que:

[...] Se comida é tratada como código, as mensagens codificadas serão encontradas no padrão de relações sociais sendo expressos. A mensagem é sobre os diferentes graus de hierarquia, inclusão e exclusão, limites e transações através de limites. Como sexo, o falar de comida tem um componente social, tanto quanto biológico (DOUGLAS apud SMITH, 2001, p. 30).

A comida, portanto, se apresenta como um "código social" que expressa os padrões de relação social que definem grupos e seus valores. Esses códigos são expressos através do que se come, como se come, quando se come e com quem se come. A alimentação de um povo passa por mudanças e influências ao longo da história, mas sempre há alguns elementos que marcam a cultura e/ou o modo de ser daquele povo. Assim, há alimentos que servem como marcadores étnicos e carregam em si a identidade de um povo. Tal fato pode ser desdobrado e/ou identificado em grupos específicos, os quais optam por alimentos que o identificam e/ou que estavam disponíveis. Isso também pode acontecer através da abstenção de um alimento ou de um grupo alimentar específico. Tal distinção pode ser realizada ou estabelecida com vários fins, desde uma distinção social entre ricos e pobres, a categorização de puros e impuros, a identificação do que é honrado ou desonrado etc.

Cláudio Carlan lembra que várias personagens ricas e pobres contribuíram para criar hierarquias gastronômicas e enológicas, permitindo o bom servir à mesa para manter sua categoria social, honrar seus convidados e distinguir seu status social da maior parte da população (CARLAN, 2012). Concordamos com Millan, quando afirma que: 
[...] $\mathrm{Na}$ alimentação humana se materializa a estrutura da sociedade, se atualiza a interação social e socioambiental, as representações socioculturais (crenças, normas, valores...) que dão significado à ação social [...] dos que têm em comum uma mesma cultura. A abstração conceitual da cultura se concretiza no prato (MILLAN, 2012, p. 99).

Portanto, o ato de comer é inerente ao ser humano, mas a forma como ele o faz é cultural, aprendido a partir do local em que se vive. Sendo assim, locais diferentes moldam culturas diferentes e, consequentemente, formas de comer variadas. No ato de comer encontramos códigos que nos indicam o formato societário estabelecido. Formato quase imutável, que detém objetivos específicos para a manutenção do poder vigente.

$\mathrm{O}$ ato de comer possui sua própria alquimia; ele transforma indivíduos em sociedade e doença em saúde; muda personalidades; pode sacralizar atos aparentemente seculares; funciona como um ritual; transforma-se em um ritual; pode fazer com que a comida seja divina vingança ou amor e pode proclamar a identidade. Uma mudança tão revolucionária quanto qualquer outra na história de nossa espécie ocorreu quando o ato de comer deixou de ser meramente prático e passou a ser também um ritual (FERNÁNDEZ-ARMESTO, 2004, p. 59).

Frente a essa afirmação, devemos indagar: por que as pessoas comem o que elas comem? Dentre os quatro fatores citados por Peter Garnsey, entendemos que gosto e cultura são pontuais. Assim, o ato de comer na antiguidade significava muito mais do que apenas se sentar ou reclinar à mesa junto a um grupo de pessoas previamente escolhido. Comida, no contexto mediterrâneo do primeiro século, era algo relativamente escasso, altamente valioso e inadequadamente distribuído. Por isso, aqueles que a possuíam exibiam excentricidades culinárias como demonstração de status.

A gastronomia ganha destaque quando queremos entender os comportamentos e os hábitos cotidianos de uma sociedade ou de várias sociedades; uma vez que a cultura difere de lugar para lugar, bem como os hábitos e os comportamentos. Assim, a refeição

denota um padrão, transmitido historicamente, de significados corporizados em símbolos, um sistema de concepções herdadas, expressas em formas simbólicas, por meio das quais os homens comunicam, perpetuam e desenvolvem o seu conhecimento e as atitudes perante a vida (GEERTZ, 1990, p. 67).

Percebemos, portanto, que o ato de comer não tem apenas o objetivo de saciar a fome, mas de identificar categorias e/ou estratos sociais, bem como reafirmar a estrutura presente na sociedade vigente. 
Assim, quando estudamos a sociedade romana ou greco-romana, nosso contexto de interesse, o que é servido em uma refeição, o local em que essa refeição é servida, quem são os participantes e quem são os excluídos, como os convidados e/ou convivas se portam à mesa, o local que estes ocupam à mesa e etc. são de suma importância para entendermos de maneira mais apropriada aquela sociedade. Pois, como os antigos romanos diziam: "Diže-me o que comes e te direi quem és".

\section{$\mathrm{O}$ ato de comer}

No ato de comer encontramos códigos que podem nos indicar valores e mensagens que estavam sendo transmitidas aos presentes e também aos ausentes, uma vez que, no caso de um banquete, o grupo que se reuniria seria estabelecido através de semelhanças sociais. Ao fazer isso, a exibição de comidas exóticas e a grande quantidade de comida e bebida eram fatores de extrema importância.

A fim de ilustrar esse fato, apresentaremos brevemente, duas obras bastante conhecidas que se utilizaram de um gênero literário chamado Simpósio ou Banquete e relatam histórias ao redor da mesa, isto é, no ambiente de refeição. São elas o Satyricon, de Petrônio, obra de 66 d.C.; e o Banquete de Platão, também conhecida como Simposium, escrita provavelmente por volta de 380 a.C. A Literatura Simpótica, como nos diz Paul Veyne, assume algumas características:

O banquete é cerimônia de civilidade [...] Pois o banquete, para todos os usos, é a circunstância em que o homem privado desfruta do que ele de fato é e o mostra veridicamente a seus pares [...] O banquete constitui uma manifestação social equivalente ao prazer de beber - ou até maior - e por isso inspirou um gênero literário, o do

"banquete", em que os homens de cultura, filósofos ou eruditos (grammatici) abordam temas elevados (VEYNE, 2009, p. 172).

No Simpósio de Platão ou Simposium, os comensais, ao estabelecerem, através do diálogo, o que aconteceria durante o banquete (atitude comum, liderada pelo simposiarca) sugerem a retirada da flautista, que acabara de entrar no espaço da refeição. Ao fazer isso, o grupo estabelece que, naquele banquete, não haveria excessos, a fim de que a discussão filosófica fosse de alta qualidade.

No Satyricon, as extravagâncias culinárias estão presentes no Banquete de Trimalcião, bem como tudo é apresentado em excesso: bebida, divertimentos e o diálogo do anfitrião. A narrativa indica status e emite uma mensagem 
específica àqueles que estavam ao seu redor, isto é, no espaço em que o banquete acontece. Os alimentos postos à mesa; os convidados; os escravos que serviam e recepcionavam; a flautista, que acompanhava a cerimônia de libação que marcava a abertura do simpósio; constituíam um ambiente socialmente estruturado com objetivos específicos.

Temos, portanto, duas histórias que ilustram grupos diferentes, com objetivos diferentes, os quais formavam estratos sociais diferentes, mas que se encontravam ao redor da mesa. As movimentações no decorrer da refeição são específicas, indicando ênfases e mensagens singulares.

Dennis Smith e Mattias Klinghardt's - pesquisadores do Mundo Mediterrâneo - afirmam que havia uma refeição tradicional comum durante o período Mediterrâneo Greco-Romano, que deixou as bases para todas as refeições ocorridas nessa época, sejam elas gentílicas, judaicas ou cristãs. Esse novo paradigma pode ser aplicado nas áreas literária e social do primeiro século a.C. ao quarto século d.C. (SMITH; TAUSSIG, 2012).

Apesar de nomenclaturas diferentes, pois o que Dennis Smith denomina "Banquete Greco-Romano", Mathias Klinghardt's chama de "Refeição Comunitária", ambos estão falando de refeição, que era caracterizada pelo ato de reclinar-se à mesa (marca do banquete formal) e organizada em dois momentos: deipnon (somente comida) e o simposium (somente bebida). Através do Satyricon de Petrônio e do Simpósio de Platão, veremos como essa estrutura comensal poderia ser realizada.

O Satyricon de Petrônio e o Simpósio de Platão, ao descreverem uma cena de banquete em suas narrativas, indicam as estruturas sociais nas quais estão inseridos. Como Smith nos sinaliza: “o banquete era uma instituição social de primeira ordem e que permeou todos os níveis da vida antiga" (SMITH, 2012, p. 24). Logo, essa era uma estrutura conhecida e difundida no Mediterrâneo antigo.

Os valores refletidos em ambos os textos eram, de fato, aqueles presentes na sociedade em que se encontravam. No caso do Simpósio de Platão, que servia como referência para a prática de banquetes em geral, a presença de Sócrates é aludida, o que faz com que esse modelo se estabelecesse como um banquete ideal, cujo objetivo principal era a busca pela virtude por meio de discussões filosóficas que aconteciam durante o Simpósio. Já no texto do Banquete de Trimalcião, presente no Satyricon, a narrativa constituiu-se de uma sátira que, através de seus exageros e da inversão de papéis, nos dá indícios da organização social estabelecida e que é caricaturada na narrativa.

Ambos os textos demonstram as estruturas sociais, bem como as dinâmicas e relações de poder existentes através do espaço utilizado para se 
realizar a refeição, dos alimentos e da bebida consumidos, e da ação dos comensais e do anfitrião.

Algumas diferenças também são encontradas, tais como: após o Deipnon, os comensais presentes no Simpósio de Platão optam por terem o simposium (a parte das bebidas) de uma forma diferente:

[...] todos assentiram em não se embriagar naquela reunião, limitando-se a beber tão-só o suficiente para sentirem prazer [...] Bem como ficou estabelecido, disse Erixímaco, que beberemos apenas o que cada um desejar, sem constranger ninguém, propondo a seguir que a flautista que acabou de entrar seja dispensada. Que ela reserve seu instrumento a si mesma, ou, se preferir, às mulheres da casa, mas nos permita entreter-nos hoje na conversação. Se for vosso desejo, estou disposto a sugerir um tema (PLATÃO, p. 20)

A ênfase do enredo do Simpósio de Platão está na discussão filosófica, que ocorre posteriormente às deliberações dos comensais que acontecem no período de intervalo entre as duas partes da refeição. Assim, os convidados, chamados de comensais, elegem como tema de discussão a homenagem ao deus Eros; em seguida, iniciam-se as discussões e discursos em torno do tema, tendo como ápice a fala de Sócrates, ao final. Já no Banquete de Trimalcião, a ênfase recai sobre as comidas exóticas, apresentadas durante a primeira parte, e no tipo de vinho consumido - de Falerno. Aqui não há temas sugeridos para uma discussão mais aprofundada, pois o anfitrião, o liberto Trimalcião, toma a palavra em todo o tempo.

No Simpósio de Platão, os escravos aparecem na narrativa pontualmente: na recepção de um convidado e ao levá-lo até o seu local para reclinar e no servir. Eles estão presentes, mas são praticamente "invisíveis". Já no Banquete de Trimalcião, os escravos ocupam uma parte importante da narrativa e da trama desenvolvida, havendo uma valorização incomum dessas personagens que recebem extrema visibilidade.

Em ambos os textos, temos a presença de comensais previamente convidados, os quais demonstram a importância do evento ao se prepararem para o mesmo. Vejamos dois exemplos:

[...] Ele me contou que foi dar com Sócrates, o qual acabara de tomar banho e calçava seu melhor par de sandálias, dois acontecimentos esporádicos em relação a ele. Diante disso, perguntou-lhe aonde pretendia ir e o porquê da boa aparência. 'Vou jantar na casa de Agaton', respondeu [...] Assim, cuidei da boa aparência para estar em consonância com o meu belo anfitrião (PLATAO, 2012, p. 13).

[...] Vestidos com nossas melhores roupas (PETRÔNIO, p. 43).

Os anfitriões se diferem grandemente, pois, no texto de Petrônio, Trimalcião era um liberto que havia convidado homens de variados estratos 
sociais para comporem o espaço da refeição em sua casa. Desde a entrada de sua casa até o triclínio (local onde uma refeição era realizada), a exuberância e ostentação são observados. O motivo do Banquete é a própria ostentação e o autogloriar-se do dono da casa.

Já no Simpósio de Platão, Agaton, o anfitrião, reúne os amigos a fim de celebrar o prêmio recebido no Festival de Dramaturgia Ateniense. Os convidados são pessoas ilustres que compõem o alto estrato social da época. Não há descrições do espaço em questão, mas, sim, dos convidados, tal a importância que esses conferiam ao local e não o contrário.

Quando observamos os dois textos, percebemos que a estrutura social está retratada nos acontecimentos ocorridos no espaço doméstico, especificamente no espaço da refeição. Há descrição de toda a estrutura: convidados, comida, bebida, escravos que recebem e servem aos convidados, e as dinâmicas próprias de cada banquete.

No Banquete de Platão, os escravos se "mostram" invisíveis e, consequentemente, sem voz. Sua presença é pontuada pelo ato de servir e, por isso, aparecem na narrativa em alguns momentos específicos. Os escravos aqui sinalizam as pessoas que compunham o baixo estrato desse período, as quais eram como Robert Knapp (2011) classifica: pessoas comuns, invisíveis à elite, mas fundamentais para a manutenção da sociedade. Os convidados pertencem a um grupo privilegiado e optam pela conversa filosófica na busca da virtude. Os mesmos compõem um pequeno grupo de, no máximo, seis convivas, demonstrando, assim, a intimidade e a restrição peculiares. $\mathrm{O}$ anfitrião reúne um pequeno grupo de amigos do mesmo nível social, pois a igualdade, a comunhão e a boa ordem precisavam ser fortalecidas sempre! Tanto que a ênfase na discussão filosófica sinaliza o entretenimento como algo de extrema importância. Através da retórica, os convidados se exibiam, buscando a aprovação e o consequente louvor/elogio do outro. Esse banquete simboliza a estrutura social a partir da ótica da elite.

De forma completamente diferente, temos o Satyricon de Petrônio, que satiriza a estrutura social da época e, consequentemente, as relações de poder estabelecidas; pois, ao tentar imitar um banquete de elite, o mesmo se torna ridículo. Ao compor tais críticas, a construção se dá a partir do anfitrião, que é um liberto, o qual tem convidados do mesmo nível social e dá voz àqueles que estavam sem voz no Simpósio de Platão. Esse grupo, então, recebe voz e destaque no Banquete de Trimalcião; apresentados com extrema visibilidade, demonstram, através das variadas cenas, suas atitudes, sentimentos e julgamentos (PERKINS, 2009). O grupo de comensais é grande, demonstrando, quem sabe, o clamor por aceitação e abertura de oportunidades a todos. A 
ênfase na comida exótica e na bebida em excesso é um contraponto, pois essas ênfases podem expressar o desejo de projeção e status de Trimalcião, bem como indicar a escassez daqueles que pertencem ao baixo estrato, os quais se encontram presentes nessa mesa.

Parece que Petrônio constrói a narrativa do Banquete de Trimalcião em oposição ao Banquete de Platão. O real contra o irreal, a sátira que inverte os papéis e personagens contra o banquete idealizado e utópico de Platão.

Duas faces de um mesmo mundo, descritas através do espaço da refeição. Dois banquetes em que seus comensais, ao partilharem suas refeições, ingerem seus mundos idênticos, porém diferentes e estabelecidos por meio do grupo em que se está. Portanto, através do ato de comer, podemos identificar as estruturas sociais presentes em uma dada sociedade e época. Tal perspectiva nos auxilia em uma melhor compreensão das relações sociais existentes e das dinâmicas de poder estabelecidas.

Tendo esses fatos em perspectiva, recordamo-nos da comunidade cristã em Corinto e nos perguntamos se haveria ali uma comunidade judaica estabelecida; bem como se havia a presença de judeus que pertenciam a essa comunidade. Essas questões são relevantes por conta de aparentes restrições e argumentos presentes na narrativa paulina, tal como a identificação e a restrição de comer carne sacrificada aos ídolos e a identificação de dois grupos polarizados - fracos e fortes - que têm no quê e onde se come o fator de discordância entre eles.

Alfred J. Koatch, falando sobre as leis alimentares judaicas, ${ }^{2}$ afirma que o motivo de sua instituição não foi por razões de saúde e, sim, para alcançar santidade, tendo como base o texto de Levítico 11,44-45: "Eu sou o Eterno, vosso Deus, que vos fez subir da terra do Egito, para ser para vós Deus; e sereis santos, porque santo Eu Sou". Haja vista que a palavra "santidade" em hebraico é kedushá, da palavra kadosh, que significa "separado", para ser um povo santo, Israel tinha de permanecer à parte, separar-se dos seus vizinhos adoradores de ídolos. O autor ainda afirma que o Talmud assinala que se os judeus não tiverem contato com os povos vizinhos, não se confraternizariam e, consequentemente, assegurariam a sobrevivência de Israel, mantendo-o sagrado (KOATCH, 1995).

Discordamos desse autor, pois, ao observarmos o tema da comida nas narrativas bíblicas, constatamos que a linguagem da comida é utilizada

\footnotetext{
As leis de cashrut, "as quais têm sido um fator unificador para o povo judeu através dos séculos, servindo continuamente para lembrar aos judeus as suas raízes. As leis alimentares principais são estabelecidas no livro de Levítico, onde uma lista de animas casher e não casher é fornecida" (KOLATCH, 1995, p. 102-103).
} 
constantemente e com ênfases diferentes, dependendo do bloco literário em que nos encontramos. Há um jogo de significados que podem sinalizar a partilha de comida em meio a escassez, a promessa de provisão de Deus no tempo presente e no futuro àqueles que lhe são fiéis, restrições alimentares que definem a identidade de um grupo e também alimentos que se encaixam na estrutura de pureza e impureza, carregados de simbolismos de honra e vergonha, que servem como controle pela classe sacerdotal ou elitista. A comida também é utilizada como mensagem crítica às estruturas de poder e opressão estabelecidas tanto no mundo siro-palestinense como no mundo greco-romano. Fato é que a comida ou a narrativa alimentar está presente em toda a literatura bíblica e também extra-bíblica.

$\mathrm{O}$ uso das metáforas referentes à alimentação e às discussões em torno da mesa sempre estarão presentes, trazendo advertências, restrições ou novos conceitos e possibilidades. Essa pluralidade é peculiar e inerente ao cristianismo, foco de nossa pesquisa, pois o mesmo é urbano, multicultural e bilíngue; buscando sempre o diálogo com a cultura do entorno.

\section{A comida e os estratos sociais}

A partilha de uma refeição à mesa era uma atividade comum, onde indivíduos do mesmo estrato social se reuniam com seus iguais em um mesmo espaço. Tanto que, ao se transpor a soleira de uma casa, fronteira entre o público e o privado, o convidado assumia/aceitava as regras do outro, pois se tornava um igual com o hospedeiro/anfitrião.

[...] Entrar nesse círculo é renunciar a se impor, dar prova de submissão e de obediência à sociedade $[\ldots]$ em particular, o convidado não pode recusar o que lhe oferecem, a começar pelo alimento e pela bebida que, consumidos, marcam o nascimento de uma comunidade (MONTANDON, 2011, p. 33).

As tensões e relações advindas desse sistema social se mostravam presentes à mesa, representadas através das refeições, dos banquetes, do espaço ocupado, dos participantes e/ou convivas e do seu lugar à mesa. A participação em associações, em sua totalidade sempre mantida por um patrono local, também fazia parte dos itens necessários a uma boa imagem social. Tais lugares e/ou relações se tornam instituições pelas quais os indivíduos e os grupos davam sentido ao mundo em que viviam; os quais se encontravam divididos em dois polos desiguais, mas interdependentes: elite e população. Dois polos que podem ser caraterizados pelas peculiaridades do ato de comer ou na gastronomia escolhida, no espaço e na companhia em que essa se desenvolve. 


\section{O banquete}

\section{Os comensais}

Os convidados para um banquete eram recepcionados por um escravo que, após lavar os seus pés, conduzia-lhe até o ambiente da casa em que a refeição seria servida. Este ambiente era denominado triclínio, e era formado por grandes sofás, geralmente de três lugares cada um; localizava-se em um dos cômodos da casa romana (domus). Um triclínio poderia acomodar de 09 a 11 pessoas, previamente escolhidas e convidadas pelo dono da casa, o anfitrião.

Ao se acomodarem, os convidados ficavam na posição reclinada, que era a marca do status. Outras posições no ambiente de refeição (triclinio) eram indicadores de menor status, tais como estar assentado ou em pé. Na tradição grega, por exemplo, somente os homens livres poderiam se reclinar (quando havia a presença de mulheres e crianças, elas permaneciam assentadas). Já no período romano, havia uma variação dessa regra básica, em que, por exemplo, mulheres respeitáveis eram conhecidas por se reclinarem com seus homens; bem como, em alguns simpósios, o ato de uma mulher se reclinar junto a um conviva poderia indicar que ela era uma cortesã, a qual estava presente nesse período do banquete para entreter os convidados. Via de regra, a posição reclinada ${ }^{3}$ sempre indicava postura social; revelando, assim, que a mudança de postura no ambiente do banquete nunca era algo trivial.

[...] Em Roma, como na Grécia, a prática de reclinar para comer foi amplamente verticalizada através da sociedade, tanto que um costume originalmente aristocrático foi imitado pelos grupos sociais mais simples (baixo estrato). [...] Mas reclinar nunca perde a conotação de status e luxo, a marca de uma ordem privilegiada de sociedade, e de um comportamento aprendido e praticado. Ele foi indubitavelmente adotado no Império Romano, em regiões onde tal comportamento era anteriormente desconhecido, por membros da elite local, a fim de exibir sua rápida enculturação; a 'elegância dos banquetes’ está entre os costumes romanos... (DUNBABIN, 2003, p. 13).

Os convidados eram levados ao local específico onde deviam se reclinar, a fim de que o banquete fosse iniciado. Esse local, ocupado pelo convidado, sinalizava a sua posição e importância social dentre os demais convidados; sendo assim, não havia liberdade para se reclinar onde se desejasse. Se alguém assim procedesse, poderia correr o risco de ser envergonhado por algum convidado de estrato social mais alto que reivindicasse tal lugar. Os lugares

\footnotetext{
3 Wilkins e Hill nos informam que essa pode ter sido uma prática Assíria - o comer reclinado às refeições - a qual Gregos, Etruscos e Romanos parecem ter importado dos séculos 7 e 6 a.C. em diante (WILKINS; HILL, 2006, p. 5).
} 
e os seus respectivos níveis de prestígio e honra eram bem conhecidos por todos; e até disputados pelos mesmos.

Mesmo tendo como objetivo o desenvolvimento da igualdade e da amizade entre os comensais, as diferenças sociais tendiam a existir mesmo entre iguais. A competição presente nesses encontros era evidente e uma das principais atividades durante o Simpósio (vide abaixo) consistia em pagar tributo aos membros merecedores. Daí surgiam dois problemas: um deles era que membros honrados tinham comida e bebida em quantidade e qualidade diferentes; o outro consistia em ocuparem lugares no triclínio que demonstravam a sua importância, sendo diferenciados dos demais pelo lugar em que eram acomodados. Brigas por lugares não era algo incomum. ${ }^{4}$ Sendo assim, o simpósio repete ou identifica as divisões sociais que existem fora dele (SMITH; TAUSSIG, 2012).

\section{A estrutura}

O Banquete era composto por duas partes distintas chamadas de deipnon e Simpósio. ${ }^{5} \mathrm{O}$ deipnon era a primeira parte do banquete, durante a qual a refeição era servida. Após esse momento, havia a libação com vinho puro, realizada pelo simposiarca ou pelo anfitrião. Esse momento era seguido por uma oração ou um hino, realizados em uníssono pelos presentes e acompanhados por uma flautista. O acompanhamento musical servia à função ritual de salvaguardar a própria recitação e também a eficácia da oração realizada.

A seguir, o Simpósio, a parte das bebidas, tinha início. Importante destacar que, no deipnon (refeição) não havia consumo de bebida e, no Simpósio (bebida) não havia comida: eram partes distintas de uma mesma refeição e/ ou banquete.

Smith e Taussig afirmam que, antes do terceiro século, refeições cristãs eram - como todas as refeições no mundo Greco-romano - refeições reais nas quais os participantes comiam a fim de se saciar. Naturalmente, a mesa incluía uma ampla variedade de alimentos. Sua variedade e excentricidade dependia do convidado ou do respectivo significado financeiro do grupo e

4 Por isso as discussões contidas nos evangelhos sobre quem irá se assentar à direita de Deus são tão importantes, bem como o pedido de Tiago e João em Marcos 10, 35, o qual, em Mateus 20, 20, aparece na boca da mãe desses discípulos. Também no texto de Lucas 14, 7ss, Jesus aconselha a que se espere pelo convite do anfitrião, o qual indicará o local correto em que cada um irá se reclinar. Não atentar para essa regra poderia causar vergonha e humilhação. Tal fato nos indica a presença do contexto greco-romano.

5 Optamos aqui pela nomenclatura grega. O equivalente romano seria respectivamente: Cena (jantar ao final da tarde) e Convivium (a parte após a cena que era regada a bebida. Aqui poderiam acontecer apresentações musicais, danças, debates filosóficos etc. Isso dependeria do grupo). 
dos backgrounds culturais. Lembrando que o grupo que possuía acesso a essa variedade de alimentos constituía o alto estrato, pois os demais indivíduos da sociedade não participam desses banquetes, uma vez que não possuíam o mesmo status. O contato que poderiam usufruir, se assim podemos dizer, seria se fossem escravos ou servos de uma domus romana ou como clientes. Os clientes poderiam ser convidados para participarem de alguns banquetes e/ou refeições específicas, se trouxessem algum benefício ao patrono a quem estavam ligados. Esses clientes seriam encaminhados a um lugar específico no triclínio, indicando para os presentes o seu status social.

A maioria da população somente tinha acesso a grandes banquetes quando acontecia uma grande conquista do Império e esse desejasse realizar um banquete público, por exemplo. No mais, isso não acontecia. A população tinha acesso ao alimento com bastante dificuldade pois, além da escassez, nesse período, o distanciamento e/ou a diferenciação entre os estratos também se dava através dos alimentos consumidos, tal como nos diz Bustamante (2003, p. 104):

Se até o século II a.C. a alimentação das diferentes classes sociais pouco diferiu, após a expansão romana a mesa das classes dominantes distanciou-se gradualmente. $\mathrm{Na}$ época de Apício, o regime frugal circunscrevia-se aos camponeses e às camadas mais pobres da população. Anteriormente, os frutos e as saladas com ervas aromáticas faziam as delícias das mesas ricas, enquanto os substanciais pratos de leguminosas e as sopas de ervas, mesmo as bravas, apaziguavam a fome do povo. Entretanto, a situação mudou com o consumo de carne, de peixe fresco e de pães e o aumento da importação de artigos destinados a uma exibição ostensiva em banquetes.

Assim, o consumo de carne era uma prática regular somente para os ricos, bem como peixe fresco, indicadores de alto estrato. A maioria da população na era Greco-Romana tinha uma dieta principalmente de grãos e vegetais. Carnes eram servidas como pratos acompanhados por bolos de cereais ou pães. O último era indispensável para escavar o lado dos pratos, uma vez que os talheres eram desconhecidos. Quebrar o pão/partir o pão e distribuir o pão é, portanto, não um traço cristão, mas um costume rotineiro com os quais qualquer refeição deveria iniciar.

A estrutura do banquete servia a um estrato social em detrimento de outro. Deste modo, a mensagem presente nesses encontros fortalecia um pequeno grupo, bem como distanciava os demais, ou melhor, aqueles que participavam do baixo estrato; uma vez que na Antiguidade não havia ainda a categorização de classes sociais e muito menos da classe média. Ou se era rico, ou pobre, não havendo meio termo. 


\section{A comensalidade}

A prática de comer juntos é identificada como comensalidade, a qual é caracterizada pela partilha (nem sempre igual) de comida. A comensalidade pode conter vários objetivos, desde organizar as regras da identidade de um grupo, identificar os estratos sociais dos comensais e, consequentemente, distinguir o mais honrado do menos honrado ou simplesmente desfrutar um determinado período junto a um grupo de pessoas (CARNEIRO, 2005). Ela também pode provocar a desconstrução de algumas classificações existentes, tais como "puro" e "impuro", desafiando os participantes a uma prática inclusiva e mais igualitária.

O objetivo da prática da comensalidade dependerá da época em que um indivíduo ou comunidade estiverem inseridos, bem como da proposta presente na figura de um anfitrião, de um líder e/ou grupo social ou religioso a que se pertença. Tal fato se encontra presente na cultura popular quando, através do que se come e/ou daquilo que se consegue como alimento, sinaliza a condição social e consequentemente nos aponta grupos marginalizados. A comensalidade, portanto, pode ser vista, como um ato de sobrevivência, uma vez que as camadas mais pobres têm na sua subsistência o seu maior foco.

Segundo Koester, o symposia figurava como centro da vida social grega, quando grupos se reuniam regularmente para beberem juntos. Nesses encontros, além da presença obrigatória do vinho, havia interesses comuns que caracterizavam os grupos, tais como formas de cultos e laços familiares. Esse era um tipo de associação, dentre tantas do mundo antigo, na qual encontramos as associações religiosas (thiasoi), criadas para deuses e cultos que não tinham o patrocínio da comunidade política e, por isso, não dispunham de santuários reconhecidos publicamente, tal como o cristianismo. Boas relações em jantares regulares e encontros para beber eram desejáveis em todas as classes da sociedade helenística - mesmo que essas festas terminassem às vezes em brigas, arruaças e eventuais ações judiciais (KOESTER, 2005). A refeição, portanto, se mostra como um elemento agregador, delimitador e/ ou identitário presente nas diversas culturas.

Essa dinâmica pode ser observada no cristianismo primitivo, o qual tem na mesa um de seus elementos principais. Podemos observar Jesus e seus discípulos em vários momentos de refeição; a qual composta de elementos básicos da dieta popular, agregava e alimentava marginalizados e excluídos. $\mathrm{Na}$ própria ceia, ato final do Cristo, traços da cultura popular se veem retratados, assimilados e codificados em mensagens e orientações específicas àqueles/as que se encontravam presentes nessa última refeição do grupo de seguidores. 
As reuniões em torno da mesa traziam, também, o fortalecimento nos relacionamentos intracomunitários, bem como estreitavam e firmavam alianças de serviço e fidelidade, como no caso do patronato e clientelismo, estrutura social caracteristicamente romana. Compartilhar uma refeição identificava as relações sociais existentes e o grupo a que se pertencia, logo, havia obrigações implícitas aos presentes que, através da dinâmica do patronato e clientelismo, estavam envolvidos numa rede social de reciprocidade e obrigações. $\mathrm{O}$ ato de comer, portanto, servia como mediação para o status social e o poder, bem como exprimia os limites de identidade do grupo (CROSSAN, 1995).

Esse encontro poderia acontecer em um espaço público ou privado e indicava, como nos diz Crossan (cf. 1994; 1995), miniaturas das regras de associação e socialização. O grupo de pessoas presente a essa refeição representava a hierarquia social instituída na sociedade e, consequentemente, a que estrato social elas pertenciam, pois pessoas de estratos sociais diferentes ocupavam espaços diferentes no ambiente da refeição. Uma vez que a refeição dava acesso à casa e à intimidade daquele que realizou o convite, os comensais (convidados) eram aqueles que estavam à mesa com seus companheiros, com seus iguais. Tal fato nos leva a perceber a prática alimentar como algo culturalmente construído, que pode incluir, empoderar, destacar, bem como, excluir, desempoderar e, ainda, estigmatizar.

Claudia Beltrão da Rosa, ao falar sobre o banquete ritual e a ordem sagrada em Roma, diz que: "a sacralidade não é construída como um 'além', mas como o modo pelo qual uma ordem específica é consolidada ou mantida intacta (...)”. Citando Detienne e Vernant, ela concorda que:

[...] sacrifícios estabelecem relações que organizam a sociedade e instituem o lugar de cada um de seus membros: seres humanos em relação às divindades, cidadãos em relação a não-cidadãos, cidadãos entre si, e cidadãos em relação ao corpo social, a partir da divisão de um alimento ou de uma vítima, 'alimentando' as relações sociais e definindo a hierarquia cívica (ROSA, 2012, p. 68).

Nessa mesma lógica, concordamos com o historiador Paul Veyne, quando afirma que a comensalidade é um fenômeno polissêmico, pois a mesma não deriva da sociedade e tão pouco é um ato de solidariedade cívica. Ao contrário, seu primeiro objetivo é produzir o grupo, criando hábitos e comportamentos. Assim, a função de socializar seria secundária.

Assim, percebemos a presença da comensalidade como ato presente e identitário do cristianismo primitivo, que tem na refeição eucarística e comunitária sua marca. Marca que indica pertença e proximidade aos grupos cristãos 
do Mediterrâneo, fato que também se encontra descrito nos relatos canônicos e apócrifos, dada sua singularidade e proximidade da cultura popular.

\section{Conclusão}

Ao pesquisarmos o cristianismo primitivo, a refeição posta à mesa ou um breve lanche realizado na estrada, a parada em locais específicos para se comer algo junto a um grupo; uma refeição ritual e os itens que a compõem, estão cercados de interessantes propostas hermenêuticas, que nos possibilitam ir além do escrito e/ou perceber novas perspectivas do mesmo.

Observar o entorno do texto, ou melhor os pratos, as pessoas, os grupos e os espaços constituem-se em um desafio pois o ato de se estar à mesa, de fazer uma refeição, era cercado por códigos, os quais precisam ser decifrados, a fim de que entendamos com mais propriedade as mensagens ali veiculadas. O olhar precisa se desviar da grafia pura e simples a fim de perceber essa outra faceta que se apresenta com características intertextuais.

O comer e a sua estrutura se encontra presente na literatura bíblica e extra bíblica, canônica e apócrifa; tornando-se um caminho a ser trilhado na busca de novas respostas àqueles e àquelas que pesquisam essa área do conhecimento. Grupos se reúnem desde sempre para celebrar sob os mais variados motivos, e os alimentos apresentados assumem características específicas que precisam de atenção.

Reconhecemos, portanto, a importância da comida como elemento estruturante na literatura e na sociedade em geral. Por meio dela, podemos identificar as hierarquias estabelecidas em uma sociedade ou em grupos menores; o comportamento esperado daqueles que partilhavam uma refeição; as prováveis intenções de um anfitrião ao oferecer um banquete, dentre várias outras coisas. A comida apresenta códigos e envia mensagens em todo o tempo. Tais códigos, quando decifrados, podem auxiliar no entendimento de muitas coisas.

\section{Referências bibliográficas}

AGUILERA, César. História da alimentação mediterrânea. Trad. de Joaquim A. Nogueira Gil. Lisboa: Terramar, 2001.

BEARD, Mary. Pompeia: a vida de uma cidade romana. Trad. de Cristina Cavalcanti. Rio de Janeiro: Record, 2016.

BRILLAT-SAVARIN, J. A. Fisiologia del gusto. Barcelona: Editorial Óptima, 2001.

BUSTAMANTE, Regina Maria da Cunha. Em torno da mesa da Elite na Roma Antiga.

Calíope: Presença Clássica, Rio de Janeiro, v. 11, n. 7-8, p. 95-111, 2003. 
CANDIDO, Maria Regina (Org.). Práticas Alimentares no Mediterrâneo Antigo. Rio de Janeiro: NEA/UERJ, 2012.

CARLAN, Cláudio Umpierre. Vinho: comércio e poder no mundo antigo. In: CANDIDO, Maria Regina (Org.). Práticas Alimentares no Mediterrâneo Antigo. Rio de Janeiro: NEA/UERJ, 2012.

CARNEIRO, Henrique S. Comida e sociedade: significados sociais na história da alimentação. História: Questões e Debates, Curitiba, n. 42, p. 71-80, 2005.

CARNEIRO, Henrique S. Comida e sociedade: uma história da alimentação. Rio de Janeiro: Elsevier, 2003.

COSGROVE, Charles H. Banquet Ceremonies Involving Wine in the Greco-Roman World and Early Christianity. Catholic Biblical Quarterly, n. 79, p. 299-316, 2017.

COUlangES, Fustel de. A cidade antiga. São Paulo: Martin Claret, 2007.

CROSSAN, John Dominic. O Jesus Histórico: a vida de um camponês judeu do Mediterrâneo. Rio de Janeiro: Imago, 1994.

CROSSAN, John Dominic. Jesus: uma biografia revolucionária. Trad. de Júlio Castañon Guimarães. Rio de Janeiro: Imago, 1995.

CUCHE, Denys. A noção de cultura nas Ciências Sociais. 2. ed. Bauru: Edusc, 2002.

DOUGLAS, Mary. Implicit meanings. Selected Essays in Anthropology. 2. ed. London; New York: Routledge, 1999.

DUNBABIN, Katherine M. D. The Roman banquet: images of conviviality. Cambridge: Cambridge University Press, 2003.

FLANDRIN, Jean-Louis, MONTANARI, Massino. História da Alimentação. 4. ed. São Paulo: Estação Liberdade, 1998.

GARNSEY, Peter. Food and society in Classical Antiquity. Cambridge: Cambridge University Press, 2002.

GEERTZ, Clifford. A interpretação das culturas. Rio de Janeiro: Guanabara Koogan, 1990.

KNAPP, Robert. Invisible Romans. Cambridge: Harvard University Press, 2011.

KOESTER, Helmut. Introdução ao Novo Testamento. Vol. 1: História, cultura e religião do período helenístico. São Paulo: Paulus, 2005.

KOLATCH, Alfred J. Livro judaico dos Porquês. São Paulo: Sêfer, 1995.

MONTANARI, Massimo. História da Alimentação. 8. ed. São Paulo: Estação Liberdade, 2015.

MONTANDON, Alan (Org.). O Livro da Hospitalidade: acolhida do estrangeiro na história e nas culturas. Trad. de Marcos Bagno e Lea Zylberlicht. São Paulo: Senac, 2011.

PERKINS, Judith. Roman imperial identities in the Early Christian Era. London; New York: Routledge, 2009.

PETRÔNIO. Satyricon. Trad. de Paulo Leminski. 2. ed. São Paulo: Brasiliense, 1987.

PLATÃO. O Banquete. Trad. de Edson Bini. São Paulo: Edipro, 2012.

ROSA, Claudia Beltrão da. Lectistenivm: banquete ritual e ordem sagrada na Roma republicana. In: CANDIDO, Maria Regina (Org.). Práticas Alimentares no Mediterrâneo Antigo. Rio de Janeiro: NEA/UERJ, 2012, p. 60-82. 
SMITH, Dennis E.; TAUSSIG, Hal. Meals in the Early Christian world: social formation, experimentation and conflict at the table. New York: Palgrave Macmillan, 2012.

VEYNE, Paul (Org.). História da Vida Privada. Vol. I: Do Império Romano ao ano mil. São Paulo: Companhia das Letras, 2009.

Submetido em: 10-4-2020

Aceito em: 1-5-2020 